\author{
Marion Brandt \\ Uniwersytet Gdański \\ filbr@ug.edu.pl
}

\title{
Podróż po Polsce Alfreda Döblina. Kilka uwag o genezie tekstu ${ }^{1}$
}

\author{
Tłum. Marek Szalsza
}

Alfred Döblin's Reise in Polen. A Few Remarks on the Genesis of the Text

\begin{abstract}
The article presents some reflections upon the genesis of Alfred Döblin's Reise in Polen formulated on the basis of manuscripts and other materials from the writer's legacy. Among the figures of speech used by Döblin to turn his travel experiences into a literary text are anonymisation of conversations, blurring of the logistic background of the journey and staging orality. The second part of the article includes an analysis of Döblin's book from the point of view of the presence of an important thematic motif, which is the national question. It discusses the way in which the writer's views on national independence movements change in the process of writing.
\end{abstract}

Keywords: Alfred Döblin, literary account of a journey, genesis of a text, Poland, Polish Jews, nation, Zionism

Streszczenie: Artykuł przedstawia rozważania dotyczące genezy Podróży po Polsce formułowane na podstawie rękopisów i materiałów ze spuścizny Alfreda Döblina. Do zabiegów, za pomocą których pisarz przekształcił swoje przeżycia z podróży w tekst literacki, należą: anonimizacja rozmów, zamazanie tła logistycznego podróży i inscenizowanie oralności. W drugiej części artykułu zanalizowano książkę Döblina pod kątem obecności ważnego wątku tematycznego, który stanowi kwestia narodowa. Pokazano, w jaki sposób poglądy pisarza na ruchy narodowowyzwoleńcze zmieniły się w trakcie procesu pisania.

Słowa kluczowe: Alfred Döblin, literacka relacja z podróży, geneza tekstu, Polska, Żydzi polscy, naród, syjonizm

1 Tekst jest tłumaczeniem szkicu: Alfred Döblins Literarisierung der Polenreise [w:] Internationales Alfred-Döblin-Kolloquium Warschau 2013. Interkulturelle Aspekte im Schaffen Alfred Döblins (= Jahrbuch für Internationale Germanistik. Reihe A - Band 121), red. M. Brandt, G. Kwiecińska, Bern: Peter Lang 2015, s. 91-113. 
Literackie relacje z podróży mimo wszelkich związków z faktycznie odbytą podróżą zawsze stanowią „kreatywne przetworzenie” tego, co się przeżyło i zobaczyło w obcym kraju². Dotyczy to także książki Podróż po Polsce Alfreda Döblina (1925). Zamierzam przedstawić tu kilka rozważań na temat sposobu, w jaki Döblin przekształcił swoją podróż do Polski w fikcję literacką.

\section{Zamazywanie konturów}

Inaczej niż trzy lata później Tomasz Mann, Döblin nie przyjechał do Polski w roli pisarza podejmowanego jako gość przez kolegów po fachu z sąsiedniego kraju. W roku 1924 znany był on w Polsce tylko w niewielkim kręgu publicystów i pisarzy; nie przetłumaczono też jeszcze żadnego z jego dzieł. Döblin odwiedził w Warszawie, Wilnie, Lublinie, Lwowie, Krakowie i Łodzi redakcje znanych dzienników, w których przedstawiał się przypuszczalnie jako korespondent specjalny „Vossische Zeitung”. różne orientacje polityczne; i tak Döblin przeprowadził rozmowy z pracownikami syjonistycznych gazet „Chwila” (prawdopodobnie byli nimi Henryk Hescheles i Alfred Plohn) oraz „Nowy Dziennik”, fołkistowskiego „Wilner Tog” (Salman Reisen), bundowskiego „Lubliner Tugblat” (Jakub vel Jankiel Nissenbaum), socjalistycznego „Robotnika” (Feliks Perl) oraz z Konstantym Srokowskim, redaktorem gazety „Nowa Reforma”. W Łodzi odwiedził - według wspomnień dziennikarza i lokalnego historyka Otto Heikego - pomieszczenia redakcji „Lodzer Volkszeitung” (była to gazeta Niemieckiej Partii Robotniczej w Polsce $)^{5}$. We wszystkich tych redakcjach miał nadzieję znaleźć partnerów do rozmowy, a może i przewodników po miastach.

Oprócz spotkań w redakcjach istniały dla Döblina jeszcze dwa inne sposoby znajdowania rozmówców w Polsce. Niewątpliwie dostał różne adresy od

B. Korte, Der englische Reisebericht. Von der Pilgerfahrt bis zur Postmoderne, Darmstadt 1996, s. 14.

3 Wśród dokumentów dotyczących Podróży po Polsce w spuściźnie Alfreda Döblina znajdują się wizytówki z takim nadrukiem.

${ }^{4}$ Henryk Hescheles (1886-1941) dziennikarz, pisarz, redaktor naczelny „Chwili”. Alfred Plohn muzyk i krytyk muzyczny „Chwili” (nie udało się znaleźć danych biograficznych). Salman Reisen (1887-ok. 1940) filolog i historyk literatury żydowskiej, autor Leksikon fun der jidiszer literatur, prese und filologie („Leksikón fun der yídisher literatúr, prése und filológye”, 19261929), członek pierwszego prezydium Żydowskiego PEN-Klubu i współzałożyciel Żydowskiego Instytutu Naukowego (YIVO), redaktor naczelny „Wilner Tog”. Jakub vel Jankiel Nissenbaum (1893-1942) członek Ogólnożydowskiego Związku Robotniczego „Bund” (Algemejner Jidiszer Arbeter Bund). Feliks Perl (1871-1927) współzałożyciel PPS (1892) i potem członek zarządu partii, redaktor naczelny „Robotnika”. Konstanty Srokowski (1878-1935) publicysta, polityk Polskiego Stronnictwa Demokratycznego.

5 Zob. O. Heike, Leben im deutsch-polnischen Spannungsfeld. Erinnerungen und Einsichten eines deutschen Journalisten aus Lodz, red. W. Kessler, Herne 2002 (wyd. 2), s. 55 i n. 
syjonistów, z którymi spotykał się w Berlinie i którzy częściowo zachęcili go do odbycia podróży ${ }^{6}$. Nie dałoby się inaczej wyjaśnić tego, że mógł spotkać się z najznaczniejszymi syjonistycznymi politykami Drugiej Rzeczpospolitej, mianowicie z Izaakiem Grünbaumem i Ozjaszem Thonem ${ }^{7}$. Do niewielu partii politycznych, które wymienia w tekście, należy też Poalej Syjon, syjonistyczna partia robotnicza. Inne możliwości rozmów otworzyli przed Döblinem socjaldemokraci i liberalni demokraci, jak Georg Bernhard, redaktor naczelny „Vossische Zeitung”, który wspierał podróż pisarza. Znajomym Bernharda był Ulrich Rauscher, niemiecki przedstawiciel dyplomatyczny w Polsce, którego adres pojawia się wielokrotnie w notatkach Döblina i który mógł - jako że był tak jak Döblin członkiem SPD - znaleźć mu partnerów do rozmowy wśród polskich socjalistów. Rolę cicerone Döblina po Warszawie odegrał przypuszczalnie Alfred Krygier, członek Polskiej Partii Socjalistycznej (PPS) ${ }^{8}$, której organ prasowy „Robotnik” pojawia się w książce jako „lewicowa gazeta”.

O tym naszkicowanym tu zaledwie organizacyjnym szkielecie czy też tle podróży czytelnik lub czytelniczka książki Döblina dowiaduje się tylko niewiele - tak, jakby jej autor przy użyciu specjalnego obiektywu celowo rozmazał kontury swej podróży. Na próżno szukalibyśmy w książce nazwisk rozmówców, zamiast tego dowiadujemy się, że Döblin rozmawiał na przykład z „przywódcą syjonistów, brodatym, żywym, niezwykle energicznym mężczyzną" (PP 72), pojawiają się między innymi „wykształcony Żyd, oświeceniowiec” (PP 229), czy „dziennikarz, szczególnie mądra głowa, filolog, jidyszysta-pasjonat” (PP 124).

Z jakiego powodu Döblin umieszcza swoich rozmówców i towarzyszy podróży na drugim planie?

Nierzadko podaje w swojej książce błędne informacje, na co wskazują Anna Wołkowicz, tłumaczka Podróży po Polsce, oraz Henryk Grynberg, który napisał posłowie do polskiego wydania ${ }^{10}$. Notując $w$ trakcie swoich rozmów ogromną ilość liczb i informacji, Döblin sam musiał być świadomy niepewności przytaczanych faktów. Nie mógł być pewien, czy wszystko oddaje

${ }^{6}$ Por. H.O. Horch, Nachwort [w:] A. Döblin, Schriften zu jüdischen Fragen, red. H.O. Horch, München 1997, s. 524-580, szczególnie s. 537; także A. Döblin, Autobiographische Schriften und letzte Aufzeichnungen, red. E. Pässler, Olten, Freiburg i. Br. 1980, s. 211.

7 Izaak Grünbaum (Jizchak Grynbaum, 1879-1970), przywódca syjonistyczny, poseł na Sejm i przewodniczący Żydowskiej Rady Narodowej, od 1933 roku w Palestynie, był sygnatariuszem Deklaracji niepodległościowej Izraela i pierwszym ministrem spraw wewnętrznych Izraela. Dr Ozjasz Abraham Thon (1870-1936) rabin, przywódca syjonistyczny, poseł na Sejm, członek Komitetu Delegacji Żydowskich przy Konferencji pokojowej w Wersalu i w 1918 roku współzałożyciel „Nowego Dziennika”.

${ }^{8}$ Alfred Krygier (1887-1956) pisał między innymi dla „Robotnika” i był aktywny w ruchu spółdzielczym. Jego nazwisko pojawia się w notatkach wielokrotnie, raz występuje tam też jego żona, Stefania Krygier (1895-1951), lekarka, która również była członkinią PPS.

9 A. Döblin, Podróż po Polsce, tłum. A. Wołkowicz, Kraków 2000, s. 41, dalej jako PP.

${ }_{10}$ Zob. A. Wołkowicz, Nota ttumaczki [w:] A. Döblin, Podróż po Polsce, dz. cyt., s. 310; H. Grynberg, Postowie [w:] A. Döblin, Podróż po Polsce, dz. cyt., s. 315 i n. 
poprawnie. Nazwiska zapisywał ze słuchu i często je zniekształcał (na przykład Meier Ballaban zamiast Majer Bałaban). Do tego dochodzi fakt, że jego rozmówcy wygłaszali niekiedy kontrowersyjne opinie, które być może niechętnie ujrzeliby w druku. Wypowiedzi znanych polityków Döblin musiał prawdopodobnie nawet poddawać autoryzacji. Uciekając się do zabiegu anonimizacji, zyskiwał możliwość kreatywnego przetwarzania dialogów oraz wolną rękę w ich fikcjonalizacji. Tak więc mógł rozdzielić jedną rozmowę (na przykład z Józefem i Haliną Wittlinami w Łodzi) na wiele dialogów z różnymi osobami, lub odwrotnie, połączyć kilka rozmów w jedną. Uznanego syjonistycznego polityka Ozjasza Thona z pewnością nie sportretowałby tak jednostronnie jak żydowskiego „oświeceniowca” w rozdziale o Krakowie (PP 229).

Unikając naszkicowania logistycznego tła swojej wizyty, Döblin umniejsza znaczenie towarzyszy podróży oraz rozmówców, przez co stwarza wrażenie, jakby w głównej mierze badał Polskę bez pomocy innych osób. Powstaje przez to obraz bezpośredniego przeżywania i niemal naiwnego oglądu. Najwyraźniej o takie właśnie „niesterowane” spojrzenie mu chodziło. Skarży się co prawda na to, że w Wilnie i Lublinie miał gorszą opiekę niż w Warszawie i że niewiele osób mu tam towarzyszyło, ale już w Krakowie sam odłączył się od swojej przewodniczki po mieście, ponieważ pokazywała mu tylko sztukę, tymczasem jego interesowali ludzie (porównywalny bunt przeciwko perspektywie przewodników nastąpił już w Lublinie przy Bramie Grodzkiej). Ów konflikt między oglądem własnym a sterowanym Döblin w bezpośredni sposób opisuje w rozdziale o Zakopanem, w którym narrator, po tym, jak podejmująca go Niusia pokazuje mu wieś, konstatuje: „Już nie czuję obcości, dystansu. Nagle jestem tu już od sześciu tygodni” (PP 256).

Przez to, że tekst nie eksponuje bycia oprowadzanym, lecz samotną eksplorację zwiedzanego kraju, oddane zostaje wrażenie „obcości, dystansu”: nowe otoczenie nie staje się swojskie. Obcość tę wzmacnia jeszcze to, że Döblin wplata w swój tekst niewiele nazw takich miejsc, jak hotele, kawiarnie czy restauracje. $\mathrm{Z}$ notatek, a także z rękopisu dowiadujemy się, że w Łodzi najpierw prosił o pokój w hotelu Polonia, a w Warszawie mieszkał w Bristolu (tak czytamy jeszcze w przeddruku), w Wilnie w Europie, w Drohobyczu w Boulevard, w Krakowie w Hotelu Francuskim. Z nazw kawiarni wymienia tylko kilka w Warszawie i Lwowie - inne to na przykład kawiarnia artystyczna Walter w Warszawie, sławne kawiarnie Rudnicki i Sztrall w Wilnie, Café Szolc w Drohobyczu, Café Seidel w Gdańsku. Nazwy hoteli, podobnie jak nazwy kawiarni i restauracji, świadczyłyby o pewnym, choćby tylko tymczasowym oswojeniu objeżdżanego kraju - zwłaszcza że możemy wyobrazić sobie Döblina również piszącego w tych lokalach. Wiele wskazuje jednak na to, że chciał on uniknąć takiego wrażenia. Narratorowi, który sam eksploruje kraj, przyznaje pewną suwerenność, tym większą, im bardziej obce zdaje się otoczenie. Ta suwerenność stanowi fundament wszelkiej krytycznej refleksji o rzeczach ujrzanych i usłyszanych. 


\section{Inscenizowanie oralności}

Döblin z rzadka tylko wykazuje źródła pisane, które wykorzystał w swojej książce. Niekiedy twierdzi nawet, jakoby sam nie czytał informacji zaczerpniętych w rzeczywistości z literatury, a jedynie je zasłyszał. Na przykład zarys historii Łodzi rozpoczyna zdaniem: „Lubię słuchać o dawnych czasach” (PP 271). Jego następujące po tym wywody włącznie z cytatami pochodzą jednak ze źródła pisanego, a konkretnie z artykułu O historii miasta Łodzi, który ukazał się w jubileuszowym wydaniu „Lodzer Zeitung” z roku $1913^{11}$. Na ten sam zabieg oralizacji źródeł pisanych natykamy się w rozdziale o Krakowie, gdzie autor pisze: „Opowiadają mi trochę z pradawnej Sefer Jecira” (PP 226), a następnie przytacza cytaty wzięte (z drobnymi zmianami) z wydania Sefer Jecira $\mathrm{w}$ przekładzie Lazarusa Goldschmidta ${ }^{12}$.

Wrażenie opowieści ustnych wzmocnione jest jeszcze przez to, że Döblin wplata te wiadomości, które zaczerpnął z literatury, w swoje spacery po miastach, sugerując, jakoby poznał te opowieści właśnie podczas przechadzek z ust jakiegoś towarzysza lub przypadkowego rozmówcy. Dotyczy to na przykład informacji o postawie duchownych podczas powstania styczniowego w latach 1863-1964: Döblin przytacza je w połączeniu z wrażeniami z warszawskich kościołów, choć zaczerpnięte są z publikacji Emila Knorra Die polnischen Aufstände seit 1830 in ihrem Zusammenhange mit den internationalen Umsturzbewegungen [Polskie powstania od roku 1830 w powiazaniu z międzynarodowymi ruchami wywrotowymi] (Berlin 1880). Kiedy opowiada o „[z]abawnej wojnie Żydów radomskich z ich rabinem" (PP 75), o incydentach zakłócających święto Jom Kippur (PP 86), o Baal Szem Towie i znaczeniu cadyków czy też o Hucułach, również cytuje i parafrazuje, nie zaznaczając tego wcale, różne źródła pisane.

Dzięki tym zabiegom to, że książka o Polsce powstała w znaczącym stopniu dzięki lekturom, a nie tylko dzięki obserwacjom i przeżyciom z podróży, przestaje być widoczne. Döblin inscenizuje oralność i bezpośredni ogląd, przydając ulicy większe znaczenie, niż miała ona dlań rzeczywiście podczas podróży. Przenosi też na ulicę rozmowy, które z pewnością się tam nie odbyły ${ }^{13}$. Dla budowy poszczególnych rozdziałów ulice mają znaczenie zasadnicze: ciągną się niczym wątki narracyjne przez portrety kolejnych miast. Döblin snuje swą

${ }^{11}$ H. Kriese, E. Kaiser, Zur Geschichte der Stadt Lodz [w:] Jubiläumsschrift der „Lodzer Zeitung” 1863-1913, red. A. Thiele, Łódź, 2.12.1913, s. 10-27. Przedruk [w:] Lodz - „Gelobtes Land". Von deutscher Tuchmachersiedlung zur Textilmetropole im Osten. Dokumente und Erinnerungen, red. P.E. Nasarski, współpr. E. Effenberger, Berlin-Bonn 1988, s. 21-44.

${ }_{12}$ Zob. M. Brandt, Die verschlossene Tür. Alfred Döblins Zugang zum Ostjudentum vor dem Hintergrund seiner Notizen zur "Reise in Polen” [w:] 'Tatsachenphantasie'. Alfred Döblins Poetik des Wissens im Kontext der Moderne. Internationales Alfred-Döblin-Kolloquium 2007, red. S. Bekker, R. Krause, Frankfurt a.M. 2008, s. 227-238, szczególnie s. 233.

${ }_{13}$ Zob. tamże, s. 236. 
opowieść przede wszystkim wzdłuż głównych ulic, które często, wraz z przedłużeniami i przecznicami, przemierza od jednego końca do drugiego. $\mathrm{Z}$ ulic tych wyczytuje zdarzenia historyczne, stosunki społeczne, materialną i ekonomiczną sytuację ludzi oraz ich mentalność. Na przykład w Warszawie opowiadanie o wydarzeniach z historii Polski, a zwłaszcza polskiej walki o niepodległość, powiązane jest z nazwami ulic (Romualda Traugutta, aleja 3 Maja), pomnikami (Stanisława Augusta Poniatowskiego, Adama Mickiewicza), kościołami i budynkami - jak na przykład Cytadela. Döblin wplata tu zaczerpniętą z lektury (głównie Knorra) wiedzę jako opowieść powiązaną z tymi miejscami. W ten sposób już w Podróży po Polsce stwarza coś, co później rozwinie w powieści Berlin Alexanderplatz: miasto staje się tekstem, czytelnym dla kogoś, kto porusza się jego ulicami.

\section{Kontynuacja podróży}

Jak wykazuje porównanie notatek, rękopisu, przeddruku i pierwszego wydania Podróży po Polsce, wielu informacji otrzymanych w trakcie podróży, a także niektórych swoich przeżyć Döblin wcale nie umieścił w książce. $\mathrm{Z}$ drugiej strony podczas procesu twórczego wzbogacał tekst licznymi cytatami, wizjami i nowymi refleksjami. W notatkach nie występuje na przykład temat opozycji między epoką nowoczesności oraz przednowoczesności (do około 1800 roku), który zajmuje centralne miejsce w rozdziale o Krakowie. Döblin nie krytykuje w nich jeszcze syjonizmu ani szkół żydowskich jako „zachodnich instytucji z narodowym sztafażem” (PP 128), nie pisze też jeszcze o państwie i jednostce. Również samokrytyczne refleksje, snute na przykład w Café Warszawa we Lwowie lub przy ul. Grodzkiej w Krakowie, pojawią się dopiero później. Brak obszerniejszych refleksji w notatkach jest w pełni zrozumiały, ponieważ podczas samej podróży Döblin usiłował przede wszystkim wchłonąć jak najwięcej treści. W trakcie rozmów dosłownie zasypywano go informacjami, miał więc niewątpliwie dość pracy z zapisaniem wszystkiego, co zobaczył i usłyszał. Żeby sformułować jakieś stanowisko - zwłaszcza zaś ugruntowane stanowisko polemiczne, które zajął później - potrzebował czasu i dystansu. Po powrocie do Berlina Döblin niejako kontynuował więc swoją podróż, pogłębiając tematy, które wzbudziły jego zainteresowanie, jako „jazdę przy drzwiach zamkniętych" ${ }^{14}$, czyli poprzez lekturę. Zastosował tym samym również wobec Podróży po Polsce metodę charakterystyczną dla jego twórczości powieściowej, mianowicie włączenie literatury naukowej, podróżniczej, źródeł historycznych i tym podobnych do tekstu literackiego. Tak na przykład swoje spotkanie z duchowością

${ }^{14}$ A. Döblin, Schicksalsreise. Bericht und Bekenntnis, München, Zürich 1986, s. 113. 
Żydów wschodnich wzbogacił różnymi lekturami dotyczącymi kabały i chasydyzmu ${ }^{15}$.

Inny temat, którym Döblin nadal zajmował się w Berlinie i który pogłębił w tekście przez lekturę i refleksje, to zagadnienie narodu. Szczególne znaczenie problematyki narodowej w Podróży po Polsce wynika z różnych okoliczności. Döblin w swoim zamiarze poznania niezasymilowanych Żydów wspierany był - jak już wspominałam - przez syjonistów, do których programu politycznego zbliżył się przed podróżąa ${ }^{16}$ W jego relacji o Żydach wschodnich refleksja dotycząca syjonizmu i żydowskiego ruchu narodowego zyskała więc szczególną wagę. Również lektura dzieła Simona Dubnowa Neueste Geschichte des jüdischen Volkes [Najnowsza historia narodu żydowskiego ${ }^{17}$ musiała uświadomić mu, jakiego znaczenia nabrała dla Żydów wschodnioeuropejskich idea narodowej emancypacji. Jako że notatki z podróży zawierają odniesienie do konkretnego fragmentu owej książki („zob. III tom Dubnowa s. 339; replika Güdemanna [?] przeciwko nacji Żydów" $\left.{ }^{18}\right)$, można zakładać, iż ostatni tom tego dzieła zatytułowany Die Epoche der zweiten Reaktion (1881-1914) [Epoka drugiej reakcji (1881-1914)] wziął nawet ze sobą w podróż. Kolejnym czynnikiem, który tłumaczy szczególną wagę problematyki narodowej, było zetknięcie Döblina z odrodzonym państwem polskim.

Jak pokazują przeróbki rękopisów i przeddruków odnoszących się do tego tematu, Döblin w trakcie pisania książki intensywnie zajmował się problematyką narodową, a wręcz to właśnie wówczas wypracowywał sobie postawę wobec dążeń do niepodległości, samodzielności i separacji narodowej. Spróbuję tu krótko naszkicować ten proces.

W zapiskach z podróży da się znaleźć tylko jeden fragment zawierający szczegółową refleksję na powyższy temat. Znajduje się on wśród notatek, które Döblin sporządził podczas pobytu w Lublinie:

Polacy posiadają uniwersytet i tworzą de facto numerus clausus, nie dają mniejszościom ustawowych szkół, nie legalizują ich egzaminów. Sprawa jest niejasna, sytuacja polityczna mniejszości [?] niewyjaśniona, jeszcze niewywalczona. Polska nie zakazuje, tylko pozostawia sprawy sobie samym. Wymaga tego też sytuacja finansowa, bo brak środków na stworzenie tylu [?] szkół, co obejmuje również nauczycieli. Jednak zamiar xxx polonizacji jest obecny. Wynika to bezpośrednio z tego [?], że państwową szkołą podstawową jest jedynie obowiązkowa szkoła polska. Polacy stoją w obliczu trudnej i właściwie niespotykanej sytuacji. Naturalną tendencją państwa jest

15 Por. M. Brandt, dz. cyt., s. 233.

${ }^{16}$ Por. koncepcję referatu Zion und westliche Kultur, marzec 1924 [w:] A. Döblin, Schriften zu jüdischen Fragen, dz. cyt., s. 267-270.

17 S. Dubnow, Die neueste Geschichte des jüdischen Volkes, t. 1-3, Berlin 1920-1923.

18 Deutsches Literaturarchiv Marbach, Nachlass A. Döblin, „Reise in Polen”, sygn. 97.7.401. O znaczeniu Dubnowa dla Döblina i jego oglądu spraw żydowskich por. H.O. Horch, dz. cyt., s. 566-569. 
ujednolicanie./ Istnieje niewiele rzeczy wspólnych, z wyjątkiem [?] ziemi, między [tekst urwany]/ Trzeba rozróżniać między nacjami: nacje z rozwiniętą świadomością narodową i inne z niewielką./ Ogólna kultura zachodnia: tędy [?] istnieje polityczna tendencja Polski. Ale nie pod względem kulturalnym. Bo akurat Francja jest świecka. Stąd łatwość wcielenia. I też Ameryka. Ale Polska jest katolicka - a nawet kulturalnie (co zrozumiałe) słabo rozwinięta. Jak ma zasymilować wyższą kulturę. Ja z mojej strony nie chciałbym tego zatajać i powiedziałbym Polakom: że właściwie nie mają powodów do przesady. Nie stali się panami polskiego państwa własnymi siłami: to ententa, nie zaś Polacy, stworzyła militarnie i wojennie Polskę jako państwo. Wnikliwi Polacy wiedzą o tym i wyrazili to: nie można uciskać obcych nacji; istnieje, jak to właśnie w fascynujący i poruszający sposób pokazuje Polska, władza siły przywódczej, której nie da się całkowicie usunąć za pomocą środków politycznych. Grupa ND jest dumna, apodyktyczna, nacjonalistyczna, jej istnienie jest niezbędne i całkiem naturalne./ Uważam linię piłsudczyków za najzdrowszą i najbardziej przyszłościową./ Wydaje mi się, że kierunek ND jest bardzo wygodny. Polskę posadzono w siodle; musi teraz pokazać, że umie jeździć konno ${ }^{19}$.

Ta notatka Döblina ukazuje jego niewielką w tym momencie znajomość najnowszej historii Polski - gdyż bez militarnej, politycznej i dyplomatycznej zręczności polskich polityków z pewnością nie doszłoby do powstania Drugiej Rzeczpospolitej. Zdradza ponadto, że jego rozważania o kwestiach narodowych wyszły od obserwacji państwa polskiego i jego polityki wobec mniejszości. Cytowane tu notatki nie znalazły się w książce. Döblin w trakcie procesu pisarskiego wielokrotnie przerabiał swoje przemyślenia na temat kwestii narodowej. Zmiany te przedstawiam poniżej, skupiając się na trzech aspektach:

a) emancypacji narodowej ogólnie,

b) polskiej walce wyzwoleńczej,

c) żydowskim ruchu narodowym.

\section{a) Emancypacja narodowa}

Najliczniejsze przeróbki i uzupełnienia dotyczące problematyki narodowej znajdują się w rozdziale o Lwowie. Po wizytach w różnych szkołach Döblin wielokrotnie zmieniał i wzbogacał swoje refleksje. Zaczynają się one w książce od zdania: „Jest coś przerażającego w dzisiejszym nacjonalizmie” (PP 175), a kończą na słowach: „Tu musi utorować sobie drogę naturalna symbioza narodów, w kształcie lepszym i swobodniejszym niż dziś” (PP 177). W pierwszej wersji maszynopisu ten fragment tekstu brzmiał następująco:

19 Deutsches Literaturarchiv Marbach, Nachlass A. Döblin, „Reise in Polen”, sygn. 97.7.402. Zastosowano następujące znaki diakrytyczne: \{\} - tekst wykreślony, || tekst dodany, / akapit, xxx - litery niedające się odcyfrować, [ ] - tekst od wydawcy. Pominięte końcówki słów zapisane są w pełnym brzmieniu. 
To coś przerażającego. Wszyscy oni prą do tych samych zachodnich źródeł edukacji. Obok tego dumnie kroczy ich język i ich historia, jak najostrzej oddzielona od innych. Wiem, jak uczy się takiej „historii”. Hoduje się połączenie megalomanii z niewiedzą. Średniowiecze nie znało tej pychy i nowoczesnej niedorzeczności. Duchowość katolicyzmu tłumiła takie xxx partactwo. Wiem, jak uczy się „wolności”: przez nienawiść do sąsiadów. (...) Dzisiejsze państwa już od dawna nie są zbiornikami nacji, Rosja z tuzinem narodów czy Anglia, a państwo stało się już inną wspólnotą niż naród. Wydaje mi się nonsensem robić krok wstecz i okaleczać państwa, redukując je znowu do narodów. Państwo porządkuje narody. Narody zmieniały się i mogą się zmieniać. Nacja narosła na chłopskiej podstawie jest czymś małym; potrzebuje związku z otoczeniem; powiedziała A i przychodzi czas na B: zaanektowanie przez innych albo aneksję innych, a potem na całe $\mathrm{ABC}$ z wzajemnym wpływem i wzajemnym odnarodowieniem. Metody wzajemnego odnarodowienia są jednak zwykle [?] podłe [?]; zamiast wpływu następuje gwałcenie i zaraz pojawia się strach, tak zwany ruch niepodległościowy, samoizolacja, krok wstecz. I oto siedzą potem, przerażeni, zgwałceni, we wszystkich tych szkołach, polskich, ukraińskich, żydowskich i jakich tam jeszcze, nadymając własną przeszłość, rojąc przy tym o nowoczesności i prąc w stronę zachodniego uniwersalizmu./ Wiele szkód wyrządzają metody narodów, które nie posiadają legitymizacji do stosowania przemocy ${ }^{20}$.

W korekcie Döblin uzupełnił jeszcze ostatnie zdanie, pisząc: „Wielkie państwa mądrzeją i wyzbywają się swojej wrogości”. Jego krytyka skierowana jest tu przeciwko dążeniu do wyzwolenia narodowego jako takiemu, które określa mianem "tak zwanego ruchu niepodległościowego” i ocenia bardzo negatywnie jako „samoizolację" i „krok wstecz”. Państwo narodowe jest dla niego anachronizmem. Jako alternatywę mógł mieć przed oczyma państwa wielonarodowe, federacje. W zacytowanym fragmencie wymienia Rosję i Anglię, w innym miejscu jako przykład podaje Stany Zjednoczone. W przeddruku, gdzie fragment ten zbliża się już do wersji wydrukowanej w książce, Döblin mówi o „luźnych federacjach” i o „praktycznych grupach roboczych” które powinny zastępować „stare państwa” (miał zapewne na myśli państwa narodowe). W wydaniu książkowym nie znajdujemy jednak ani odrzucenia „tak zwanego ruchu niepodległościowego”, ani wyobrażeń na temat federacji.

Do cytatu ze sztuki Friedricha Schillera Wilhelm Tell: „Bo władza tyranów ma kres”, który stanowi część motta Podróży po Polsce, Döblin nawiązuje dopiero w późnej fazie pracy nad tekstem. Dramat Schillera, opowiadający o walce wyzwoleńczej małego narodu przeciwko wielkiemu mocarstwu, przekazuje zgoła entuzjastycznie pozytywny obraz „tak zwanego ruchu niepodległościowego" uciskanego narodu i różni się tym samym diametralnie od pierwszych rozważań Döblina na temat kwestii narodowej. Konflikt między Austrią i Szwajcarią pozostaje w sprzeczności z wyrażonym tam przez Döblina

${ }^{20}$ Deutsches Literaturarchiv Marbach, Nachlass A. Döblin, „Reise in Polen”, sygn. 97.7.405. 
twierdzeniem, że „duże państwa mądrzeją” i że dążenie do narodowej suwerenności stanowi „krok wstecz”. Uderzające jest to, że niemal wszystkie odniesienia do motta: „Bo władza tyranów ma kres” pojawiają się dopiero w książce. Znajdują się one tam w rozdziałach o Warszawie, Lwowie i Łodzi, tymczasem w rękopisie cytat z Wilhelma Tella zamieszczony jest na samym końcu, mianowicie w rozdziale „Wyjazd”, gdzie następnie w druku (PP 304) już nie występuje:

Czymś innym, drugim najsilniejszym, jest dusza. Jest ona gigantyczna. Myślę, że ma swój udział we wszystkim, co przed sobą widzę. Za sobą widziałem narody; wiem, co muszą dźwigać i czego pragną. Zmieniają wszystko - razem lub przeciwko sobie - jak chcą. Są wytwórcami; wszystkie instytucje są [tekst urwany]. Władza tyranów ma kres ${ }^{21}$.

Odniesienia do motta $\mathrm{z}$ Wilhelma Tella, a więc do najważniejszego zdania książki, przypadają zatem na jeden z ostatnich etapów procesu twórczego i zostały „wstecznie” włączone do tekstu przez Döblina. Podobnie jak inne opisane tu zmiany w tekście pokazują one, że Döblin w trakcie pisania zrewidował swój z początku nader krytyczny stosunek do ruchów narodowowyzwoleńczych. Jednym z powodów tej zmiany mogło być zajęcie się tematem polskiej walki o niepodległość.

\section{b) Polska walka o niepodległość}

Podróż Döblina do Polski była przede wszystkim podróżą do polskich Żydów. O samej Polsce pisarz wiedział niewiele, jak to już pokazuje zacytowana wcześniej notatka z Lublina. Polskę na początku lat dwudziestych ujmował głównie z perspektywy polskich Żydów. Mianowicie w tekście Syjon i Europa z roku 1921 pisał:

Trzeba stwierdzić, czy w Polsce i Galicji rzeczywiście żyją miliony Żydów wschodnich. Następnie należy przeprowadzić plebiscyt. Hasło powinno brzmieć: Nie syjonizm, lecz polonizm. Zakątek Polski-Galicji jest zdrowszy niż Palestyna. Z tamtego wynikłoby tylko jeszcze jedno państwo bałkańskie; ale ludziom można pomóc tylko przez ochronę państwową. Polacy będą się pienić na taki zamiar. Z ich piany nie trzeba robić dramatu. Polacy: Jasio bez ziemi. Żydzi: Jasio bez ziemi: to stanowi komplet. Jedyny warunek: rzeczywista Liga Narodów ${ }^{22}$.

${ }_{21}$ Deutsches Literaturarchiv Marbach, Nachlass A. Döblin, „Reise in Polen”, sygn. 97.7.396.

22 A. Döblin, Zion und Europa (August 1921) [w:] tegoż, Kleine Schriften I: 1902-1920, red. A.W. Riley, Olten, Freiburg i. Br. 1985, s. 313-319, tu s. 318. 
Znalezione w spuściźnie pisarza kartki z notatkami, dające wgląd w jego przygotowania do podróży, nie zawierają żadnych wskazówek co do polskich książek, rozmówców czy tematów i nasuwają przypuszczenie, że Döblin przygotowywał się tylko na spotkania z polskimi Żydami. To, że w trakcie podróży zaczął interesować się samą Polską, potwierdza Józef Wittlin w swojej recenzji Podróży po Polsce z roku 1927:

Miałem przyjemność goszczenia u siebie Alfreda Döblina w czasie jego podróży po Polsce. Na pytanie, co go do nas skierowało, odpowiedział, że zrazu myślał tylko o Żydach, o tej egzotycznej masie, która na Zachodzie zatraciła już teatralno-kostiumową osobliwość, a tylko w Polsce i w Rosji zachowuje odrębny charakter. Plan ten jednak uległ zasadniczej zmianie.

Z chwilą przekroczenia granicy polskiej uznał Döblin, że nie można z całokształtu życia jakiegoś kraju robić wycinków, lecz należy wszystko, co jest owym życiem, ująć w ramy jednolitej obserwacji23.

Dopiero więc po powrocie z podróży, już w Berlinie, Döblin zaczął szukać literatury o Polsce. Do jego lektur należała wspomniana już publikacja Emila Knorra Polskie powstania od roku 1830 w powiazaniu z międzynarodowymi ruchami wywrotowymi, z której zaczerpnął informacje włączone do rozdziału o Warszawie. Nastąpiło to - jak pokazują ekscerpty i notatki - dopiero na drugim etapie pracy, mianowicie podczas przerabiania rękopisu. Ten ostatni zawiera za to na samym początku, w opowieści o jeździe pociągiem do Warszawy, wykreśloną później refleksję na temat rozbiorów Polski i polskiej walki o niepodległość. Zamieszczam ją tu w całości, gdyż stanowi chyba pierwsze pisemne refleksje Döblina na ten temat:

Nizina Sarmacka, zamieszkana przez Polaków. |Tutaj| Założyli tu niegdyś silne słowiańskie państwo. $\mathrm{Na}$ jego czele stali wielcy władcy, Piastowie i Jagiellonowie. Potem los dotknął ten naród, nastąpiły triumfy i nieszczęścia. Myślę, że ten los spowodowało położenie geograficzne. Najazdy Tatarów od południa, wojny z zakonem krzyżackim na północy; pojawiła się wojownicza szlachta, duma, barwa narodu i jego słabość |zguba|: egoizm, nadmiernie wolne Ja |wojewodowie z Bożego nadania|. \{Na tę nędzę spadli |przybyli| potem\} obcy książęta: kraj był już wcześniej bezbronny, wewnętrznie rozdarty, panował chaos. I na koniec rozdarto go też z zewnątrz. Co zafrapowało mnie w losie tego narodu? Że coś takiego było możliwe w czasie historycznym, jedno stulecie temu, że dokonano podziału całego narodu i całkowicie poddano go obcej władzy. Zdarzenie jak z epoki Asyrii czy Babilonu. Wspaniałe, co stało się później. Jak ten naród się zmienił, wytworzył nowe organy./ Patriotyzm, umiłowanie wolności, wrosły w katolicyzm.// „Boże, coś (zob. kartka!”

${ }^{23}$ J. Wittlin, Podróż Döblina po Polsce [w:] tegoż, Orfeusz w piekle XX wieku, Kraków 2000, s. $457-460$, tu s. 458. 
[sic!].// Jak przemówił w roku 1863 Tymczasowy Rząd Narodowy (zob. kartka).// Caryzm został zniszczony od wewnątrz w wojnie europejskiej [tekst urwany] ${ }^{24}$.

Zarzuciwszy ten ustęp, Döblin umieścił wymienione w nim źródła (pieśń Boże, coś Polskę oraz proklamację Tymczasowego Rządu Narodowego) w późniejszych częściach książki, przy refleksji o kościołach w Warszawie.

Dopiero w późniejszej fazie powstawania tekstu Döblin zainteresował się polską walką o niepodległość i sukcesywnie dołączał tę tematykę jako punkt odniesienia do rozdziału o Warszawie, co tłumaczy uderzającą dysproporcję występującą między ukazaniem polskich powstań w tym i w następnym rozdziale, traktującym o Wilnie. Mianowicie rolę Michaiła N. Murawjowa (1796-1866), który jako generał-gubernator rosyjskiego cara na Litwie brutalnie stłumił powstanie styczniowe, Döblin spłaszczył niepoważnym opisem, nie dowiadując się właściwie niczego o szczególnym znaczeniu Wilna dla polskiej walki narodowowyzwoleńczej. Adama Mickiewicza błędnie umieścił w wileńskiej szkole - najwyraźniej nic wówczas nie wiedział o studiach Mickiewicza, o tajnych stowarzyszeniach studentów, o aresztowaniach i o ich również długofalowych skutkach - ani nawet o wielkim dziele narodowym Dziady. Nie mogło to wynikać tylko z tego, że jego rozmówcami w Wilnie byli przede wszystkim Żydzi, którzy asymilowali się raczej z kulturą rosyjską niż polską. Bądź co bądź rozmawiał w Archiwum Państwowym na Uniwersytecie im. Stefana Batorego z historykiem Wacławem Gizbertem-Studnickim, od którego mógłby się wielu rzeczy dowiedzieć, gdyby tylko zapytał. Powodem tej luki może być to, że w Wilnie Döblin wcale jeszcze nie interesował się polską walką o wolność.

Sądząc z notatek, w Krakowie usłyszał coś o działaniach Józefa Piłsudskiego w Galicji i o walce Legionów Polskich podczas pierwszej wojny światowej. Informacje te znajdują się też $\mathrm{w}$ rękopisie rozdziału o Krakowie, natomiast w wersji książkowej Döblin przerzucił je do przodu, czyli do części o Warszawie (por. PP 43). Cały akapit zawierający informacje o powstaniu listopadowym (por. PP 10) dodał dopiero po sporządzeniu rękopisu, a więc w przeddruku w lutym 1925 roku, a historia walki PPS o narodową niezawisłość, dla której miejscem narracji jest Cytadela (por. PP 38-41), pojawiła się dopiero w wersji książkowej.

Cały szereg drobnych uzupełnień, umożliwiających zrozumienie sytuacji polskiego państwa, Döblin dodał również na późniejszych etapach pracy, to znaczy już po stworzeniu rękopisu - albo w przeddruku, albo dopiero w książce. Zdanie: „Siedzą teraz we własnych domach” (PP 7, 15, 16), które stało się

${ }_{24}$ Deutsches Literaturarchiv Marbach, Nachlass A. Döblin, „Reise in Polen”, sygn. 97.7.394/1. Dla lepszej czytelności udokumentowany tu został jedynie jeden wariant rękopisu (wersja końcowa) i tylko w paru miejscach wykazane są te przeróbki, których Döblin nie wprowadzał konsekwentnie. 
mottem rozdziału o Warszawie, w rękopisie jeszcze nie występuje. Szczególnie uderzające jest to, że zarówno w rękopisie, jak i w przeddruku nie dostrzegamy jeszcze tak wyraźnego w książce poparcia Döblina dla walki o niepodległość i dla budowy Drugiej Rzeczpospolitej. Akapit rozpoczynający się od zdań: „To była walka o wolność. Komuż nie tajałoby od tego serce" (PP 41), znalazł się dopiero w książce, podobnie jak następujący fragment:

Pojmuję ogrom bezmiernie trudniej pracy organizacyjnej. Żeby się z nią uporać, potrzebny jest cały naród. Potrzebna jest duma i radość z mającego się dokonać dzieła. Radość, którą silnie współodczuwam (PP 51).

Zapisując te zdania, Döblin zapewne przewertował już wydaną w roku 1888 książkę Georga Brandesa o Polsce. Dowodem na tę lekturę mogą być niemal dosłowne zgodności między ową książką a jego własną publikacją w opowieściach o Legionach Polskich i o Napoleonie ${ }^{25}$. U Brandesa, który napisał słynne słowa: „Polskę miłuje się nie tak, jak się kocha Niemcy lub Francję albo Anglię, lecz się ją kocha tak, jak się wolność kocha"26, Döblin mógł odnaleźć entuzjastyczny zachwyt nad polską walką o niepodległość. Możliwe, że miało to na niego wpływ. Tym można by wyjaśnić fakt, że entuzjazm jego podróżnika dla polskiej walki o wolność rozwinął się dopiero w trakcie pracy nad książką.

To przypuszczalnie za sprawą wiedzy o historii Polski, którą uzyskał dzięki lekturom, Döblin zrewidował swoje sformułowane w rozdziale o Lwowie odrzucenie „tak zwanego ruchu niepodległościowego”. Na koniec dokonuje rozróżnienia między emancypacyjnym ruchem narodowym, skierowanym przeciwko władzy tyranów, a ruchem zinstytucjonalizowanym w państwie, przez to utrwalonym i z kolei przemienionym w tyranię wobec innych narodów. Ta centralna myśl, czy wręcz główne uwidocznione w motcie książki rozpoznanie wynikające z jego podróży i z całego procesu twórczego, znajduje odbicie również w postawie Döblina wobec żydowskiego ruchu narodowego.

\section{c) Żydowski ruch narodowy}

Podczas gdy w swym wykładzie o syjonizmie z marca 1924 Döblin mówi o idei narodowej jako o ,jedności ducha” na wszystkich terenach zasiedlonych przez Żydów ${ }^{27}$, w Podróży po Polsce podkreśla, że naród żydowski zjednoczony jest przez duchowość myśli religijnej, którą to duchowość przeciwstawia polityce: „Najprawdziwsi Żydzi już od dawna nie czekają na ”państwo«. Przetrwać

25 G. Brandes, Polen, Paris, Leipzig, München 1898, s. 33-34, PP 34.

26 Tamże, s. 65.

${ }^{27}$ A. Döblin, Zionismus und westliche Kultur [w:] tegoż, Schriften zu jüdischen Fragen, dz. cyt., s. 265-268, tu s. 268. 
można tylko w tym, co duchowe, dlatego też trzeba na tym, co duchowe, poprzestać. Rzeczywistość niebiańska nie spełni się w politycznej (...)” (PP 122). Również idei „żydowskiej republiki wschodniej”, której bronił jeszcze wiosną roku 1924, nie reprezentował już po odbyciu podróży do Polski. Ogólnie można powiedzieć, że podróż po Polsce doprowadziła Döblina do tego, że sceptycznie traktował emancypację żydowskiego narodu „w twardych ramach nacjonalizmu, przy jak najdobitniejszym akcentowaniu tego, co narodowe" (PP 122). Swoją krytykę żydowskiego ruchu narodowego sformułował wyraźniej w rozdziale o Wilnie, gdzie zetknął się z Żydami o dużej świadomości narodowej: choć początkowo wywarli na nim silne wrażenie, ich program edukacyjny poddał jednak krytyce. Jak dokumentują zachowane fragmenty różnych wariantów tekstu, Döblin sukcesywnie włączał swoje zastrzeżenia do książki. W notatkach nie da się jeszcze znaleźć żadnych refleksji na ten temat; nie zawierają one krytyki kulturalnego programu ruchu Tarbut czy jidyszystów, których szkoły Döblin zwiedził w Wilnie, lecz ograniczają się do podania rzeczowych informacji o szkołach. Rękopis nie zawiera też jeszcze obserwacji dotyczących emancypacji narodowej, zamieszczonej potem na początku opisu wizyty w szkołach żydowskich. Tam czytamy jedynie: „Co to za siły dążą do zmian, rozluźniają rygory, przekonuję się na własne oczy. Objaśnień udziela mi pewien wielce uczony pan (...)"28. W przeddruku Döblin dodaje między te dwa zdania wywód o narodowym ruchu emancypacyjnym Żydów wschodnich, któremu skrzydeł dodało odrodzenie państwa polskiego:

Co to za siły dążą do zmian, rozluźniają rygory, przekonuję się na własne oczy. Istnieje podobieństwo między Polakami i Żydami. Polacy przez cały wiek bez państwa, mimo że w całej swej masie na starym gruncie. Żydzi bez państwa przez dwa tysiące lat, rozproszeni po ziemi. Osobliwy przypadek sprawił, że znaczna część pozbawionego państwa narodu żydowskiego znajduje się akurat na ziemi pozbawionego ostatnio państwa narodu polskiego. Co wtedy spada na Polskę, wojna i wyzwolenie, ma też skutki dla Żydów. Układ pokojowy ich uwzględnia, stare emancypacyjne siły narodu żydowskiego mogą zaczerpną́ powietrza. Gdyż to, co sto tysięcy na Zachodzie już dawno utraciło, czyli narodowość, żyje nadal jako siła pierwotna w milionach na Wschodzie i jest czymś niepodważalnym. Wchłonięcie odprysków na Zachodzie przez inne narody dokonało się już wszędzie w sposób mniej lub bardziej kompletny, albo jest w toku; nie zmienia tego też resztka narodowego zjawiska „religii żydowskiej". Wyzwolenie, emancypacja mas dokonuje się na Wschodzie w twardych ramach nacjonalizmu, przy jak najdobitniejszym akcentowaniu tego, co narodowe. Jest to, jak już powiedziałem, inna forma narodowości niż ta dwutysiącletnia Gaona i Baal Szema. Objaśnień udziela mi pewien wielce uczony pan $(. . .)^{29}$.

28 Deutsches Literaturarchiv Marbach, Nachlass A. Döblin, „Reise in Polen”, sygn. 97.7.395/1.

29 A. Döblin, Reise in Polen. Wilno und seine Juden, „Die neue Rundschau” 1925, R. 36, nr 3, s. 300-322, tu s. 312-313. 
Inaczej niż w książce ujęta w cudzysłów „religia żydowska” nie znajduje się tu jeszcze w rozważaniach Döblina na temat przyszłości Żydów na pierwszym miejscu. Dokonując rozróżnienia między nowoczesnym ruchem narodowym i „dwutysiącletnim [myśleniem narodowym - dop. M.B.] Gaona i Baal Szema”, stawia raczej obok siebie duchowość, określoną jako przednowoczesną, i zachodni modernizm. W druku Döblin redukuje wszystkie te rozważania do jednego jedynego zdania:

Co to za siły dążą do zmian, rozluźniają rygory, przekonuję się na własne oczy. Emancypacja mas dokonuje się na Wschodzie w twardych ramach nacjonalizmu, przy jak najdobitniejszym akcentowaniu tego, co narodowe.

Objaśnień udziela mi pewien wielce uczony pan (...) (PP 122).

Jak pokazują zacytowane tu fragmenty tekstów, refleksje dotyczące problematyki narodowej wiążą się z rozważaniami o różnicach i stosunkach między Wschodem i Zachodem, o opozycji między epoką nowoczesności oraz przednowoczesności, a także ze zmianą spojrzenia na państwo. Döblin wznosi wokół tych pojęć konstrukcję z argumentów, których rozpoznanie należałoby kontynuować w innym miejscu. Przedstawione tu rozważania na temat metod zabiegów, za pomocą których Döblin przekształcił swoje przeżycia z podróży w tekst literacki, w żadnym razie nie wyczerpują zasobu obserwacji poczynionych względem rękopisów Podróży po Polsce.

Podsumowując, można powiedzieć, że Döblin przerabiał opisy swoich przeżyć w Polsce, rozmazując ich logistyczne tło i - przez inscenizowaną oralizację - na pierwszym miejscu umieszczając ulicę jako miejsce spotkań, rozmów i pozyskiwania informacji. Podczas procesu twórczego snuł refleksje o dokonanych spostrzeżeniach, ale wzbogacał też swoją wiedzę lekturami. Wielokrotnie rewidując własne poglądy, starał się o lepsze zrozumienie swoich przeżyć z podróży i osądzenie tego, co w jej trakcie zobaczył.

\section{Bibliografia}

Brandes G., Polen, Paris, Leipzig, München 1898.

Brandt M., Alfred Döblins Literarisierung der Polenreise [w:] Internationales Alfred-Döblin-Kolloquium Warschan 2013. Interkulturelle Aspekte im Schaffen Alfred Döblins (= Jahrbuch für Internationale Germanistik. Reihe A - Band 121), red. M. Brandt, G. Kwiecińska, Bern 2015.

Brandt M., Die verschlossene Tür. Alfred Döblins Zugang zum Ostjudentum vor dem Hintergrund seiner Notizen zur "Reise in Polen" [w:] 'Tatsachenphantasie'. Alfred Döblins Poetik des Wissens im Kontext der Moderne. Internationales Alfred-Döblin-Kolloquium 2007, red. S. Becker, R. Krause, Frankfurt a.M. 2008. 
Döblin A., Autobiographische Schriften und letzte Aufzeichnungen, red. E. Pässler, Olten, Freiburg i. Br. 1980.

Döblin A., Podróż po Polsce, tłum. A. Wołkowiecz, Kraków 2000.

Döblin A., Reise in Polen. Wilno und seine Juden, „Die neue Rundschau” 1925, R. 36, nr 3.

Döblin A., Schicksalsreise. Bericht und Bekenntnis, München, Zürich 1986.

Döblin A., Schriften zu jüdischen Fragen, red. H.O. Horch, München 1997.

Döblin A., Zionismus und westliche Kultur [w:] tegoż, Schriften zu jüdischen Fragen, red. H.O. Horch, München 1997.

Döblin A., Zion und Europa (August 1921) [w:] tegoż, Kleine Schriften I: 19021920, red. A.W. Riley, Olten, Freiburg i. Br. 1985.

Dubnow S., Die neueste Geschichte des jüdischen Volkes, t. 1-3, Berlin 1920-1923.

Grynberg H., Postowie [w:] A. Döblin, Podróż po Polsce, Kraków 2000.

Heike O., Leben im deutsch-polnischen Spannungsfeld. Erinnerungen und Einsichten eines deutschen Journalisten aus Lodz, red. W. Kessler, Herne 2002 (wyd. 2).

Horch H.O., Nachwort [w:] A. Döblin, Schriften zu jüdischen Fragen, red. H.O. Horch, München 1997.

Korte B., Der englische Reisebericht. Von der Pilgerfahrt bis zur Postmoderne, Darmstadt 1996.

Kriese H., Kaiser E., Zur Geschichte der Stadt Lodz [w:] Jubiläumsschrift der „Lodzer Zeitung” 1863-1913, red. A. Thiele, Łódź, 2.12.1913, s. 10-27. Przedruk [w:] Lodz- „Gelobtes Land”. Von deutscher Tuchmachersiedlung zur Textilmetropole im Osten. Dokumente und Erinnerungen, red. P. E. Nasarski, współpr. E. Effenberger, Berlin-Bonn 1988.

Wittlin J., Podróż Döblina po Polsce [w:] tegoż, Orfeusz w piekle XX wieku, Kraków 2000.

Wołkowicz A., Nota ttumaczki [w:] A. Döblin, Podróż po Polsce, Kraków 2000.

\section{Dokumenty}

Deutsches Literaturarchiv Marbach, Nachlass A. Döblin, "Reise in Polen”, sygn. 97.7.394/1, 395/1, 396, 401, 402, 405. 